\title{
Victor Hugo, Claude Gueux
}

\section{Lise Sabourin}

\section{OpenEdition}

\section{Journals}

\section{Édition électronique}

URL : http://journals.openedition.org/studifrancesi/4413

DOI : 10.4000/studifrancesi.4413

ISSN : 2427-5856

\section{Éditeur}

Rosenberg \& Sellier

\section{Édition imprimée}

Date de publication : 1 septembre 2016

Pagination : 345-346

ISSN : 0039-2944

\section{Référence électronique}

Lise Sabourin, «Victor Hugo, Claude Gueux », Studi Francesi [En ligne], 179 (LX | II) | 2016, mis en ligne le 01 septembre 2016, consulté le 18 septembre 2020. URL : http://journals.openedition.org/ studifrancesi/4413; DOI : https://doi.org/10.4000/studifrancesi.4413

\section{Ce document a été généré automatiquement le 18 septembre 2020}

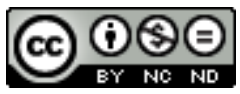

Studi Francesi è distribuita con Licenza Creative Commons Attribuzione - Non commerciale - Non opere derivate 4.0 Internazionale. 


\title{
Victor Hugo, Claude Gueux
}

\author{
Lise Sabourin
}




\section{RÉFÉRENCE}

VICTOR HUGo, Claude Gueux, édition d'Arnaud Laster, Paris, Gallimard, 2015, «Folio

classique», $137 \mathrm{pp}$.

1 En rééditant Claude Gueux, qualifié de «suite» du Dernier Jour d'un condamné (1829) par Adèle en 1863, Arnaud Laster précise, par sa préface (pp. 7-36), qu'une visite à peine ultérieure au bagne de Brest, des notes prises sur la famille de Miolis, modèle du futur évêque Myriel de Jean Valjean, pourraient bien constituer un lien entre ce bref roman, où Hugo passe de l'anonymat à la réalité d'un personnage éponyme, et la future fresque des Misérables (commencés en 1845). Ce second plaidoyer contre la peine de mort s'inspire en effet de la lecture du procès et de l'exécution de Claude Gueux, dit Lacroix (1804-1832), dans «La Gazette des tribunaux» des 19 mars, 11 avril et 15 juin 1832. Au terme de son évolution, du royalisme de 1818 au libéralisme de 1825-27 devenu libéralsocialisme en 1828, Hugo, frappé de la «sauvage éloquence» du prisonnier, l'idéalise, en en faisant un pauvre ouvrier concubin avec enfant, tout en négligeant quelques détails vrais qui auraient pu lui assurer la sympathie du lecteur (comme sa tendresse envers son père âgé également prisonnier). Il anonyme en revanche Delacelle, le gardien de Clairvaux qu'il tua, au bout de son chemin de voleur récidiviste, en en faisant un directeur des ateliers qui exploite le pénitencier plutôt que de chercher à éduquer les prisonniers.

2 Cette édition de poche, bien annotée, suit le texte de parution du roman dans la «Revue de Paris» le 6 juillet 1834, en y rétablissant les variantes et notes de Hugo ainsi que les alinéas de l'édition définitive de $1881 \mathrm{chez}$ Hetzel qui rendent les propos plus lisibles car détachés. Le dossier (pp. 81-110) fournit une chronologie hugolienne, une notice sur la réception par la presse à la sortie, les pièces du dossier criminel issues des archives de la Saône-et-Loire et de la Côte-d'Or, les adaptations du roman au théâtre en 1884 et 1895, au cinéma en 2009, en opéra en 2013, avant une bibliographie. 